\title{
Jaminan Konsumsi Rumah Tangga Petani Sagu di Desa Sungai Tohor Kabupaten Meranti, Riau
}

\author{
M. Rawa El Amady ${ }^{1,2}$ \\ ${ }^{1}$ Program Pascasarjana Sosiologi, FISIP, Universitas Riau \\ ${ }^{2}$ Scale Up, Lembaga Penyelesaian Konflik \\ mrawaelamady@gmail.com
}

\begin{abstract}
This study addresses the culture of debt as the socio-economic security of daily consumption sustainability of rural households in Sungai Tohor Village, Meranti Riau District. The village has become the target of many development programs from various institutions which focus on peat restoration and sago cultivation. Despite the programs, however, the number of poor household during and after the programs increased; from 30 households in 2015 to 50 households in 2016. This study aims at answer the question "What institution plays role in providing the security and the sustainability of daily consumption of households in Sungai Tohor Village? This study applied qualitative method. Data were collected through, library studies, participation observation, in-depth interviews with community leaders, village officials, sago factory owners and sago labors factory The study finds that tauke (big-boss) play pivotal role in the security and sustainability of daily consumption in Sungai Tohor. They are willing to provide immediate cash for the villagers for mass consumption through pajak (ijon) system. This system has helped households to survive their daily consumptions, despite the fact that this system has caused many households to lose their sago plantation. Furthermore, this system also contributes to the increase number of poor households. This research concludes that rural development program that aims to improve local economic consumption and increase the capacity of local socio-economic institution should pay attention to the local socioeconomic system and institution in order to formulate a locally-grounded program.
\end{abstract}

Keywords : tauke, culture of debt, subsistence consumption, pajak

\begin{abstract}
Abstrak
Penelitian ini membahas budaya hutang sebagai jaminan sosial-ekonomi di Desa Sungai Tohor Kabupaten Meranti Riau. Pada 2016, Desa Sungai Tohor menjadi sasaran program berbagai institusi dengan fokus restorasi gambut dan pengembangan budidaya sagu. Namun, justru pada tahun itu, jumlah rumah tangga miskin meningkat. Penelitian ini dilakukan dengan metode kualitatif. Teknik pengumpulan data dengan studi kepustakaan, observasi, dan wawancara tokoh masyarakat, aparat desa, pemilik kilang sagu dan pekerja di kilang sagu. Hasil penelitian menunjukkan bahwa petani sagu tidak memiliki jaminan konsumsi harian untuk konsumsi massal (pernikahan, pengobatan, dan pendidikan). Tauke (bos besar) menjadi lembaga jaminan rumah tangga yang sangat penting dan sangat diandalkan oleh warga karena berperan utama dalam sistem pajak (ijon) lahan sagu. Namun, sistem pajak inilah yang justru menjadi penyebab umum perpindahan tangan kebun sagu dari petani ke tauke pemilik kilang sagu. Alih-alih menyelamatkan jaminan konsumsi rumah tangga, sistem ini menjadi pemicu meningkatnya kemiskinan. Hasil penelitian menunjukkan bahwa pendekatan konsumsi dan kelembagaan sosial-ekonomi lokal perlu menjadi perhatian penting dalam merencanakan dan mengimplementasi program pedesaan dalam konteks pembangunan pedesaan.
\end{abstract}

Kata kunci : tauke, budaya hutang, konsumsi subsisten, dan pajak 


\section{Pendahuluan}

Desa Sungai Tohor di Kecamatan Tebing Tinggi Timur Kabupaten Meranti Provinsi Riau, adalah salah satu desa yang berbatasan langsung dengan Selat Malaka. Secara ekonomi, desa-desa di wilayah kecamatan ini tidak terlibat langsung dengan pemanfaatan sumber daya laut walaupun berbatasan langsung dengan Selat Malaka; terutama Desa Sungai Tohor.

Sagu adalah andalan penghidupan warga Desa Sungai Tohor. Hampir setiap rumah tangga di desa ini memiliki kebun sagu, dan hanya sebagian kecil (sekitar 50 rumah tangga) yang tidak lagi memiliki kebun sagu. Di desa ini juga terdapat 13 pabrik sagu rakyat; sepuluh desa lainya bergantung pada budi daya karet, kelapa dan pinang.

Pada 2016, Desa Sungai Tohor dijadikan lokasi program awal untuk gerakan restorasi gambut, seperti skat kanal, penanaman kembali, penguatan ekonomi rakyat dan lainlain. Program-program tersebut melibatkan berbagai pihak baik itu pemerintah pusat, pemerintah daerah, universitas dan NGO lokal dan internasional. Berbagai pejabat sudah pernah berkunjung ke Desa Sungai Tohor mulai dari pejabat daerah, Menteri Kehutanan dan Lingkungan Hidup hingga Presiden Jokowi. Bahkan program-program ekonomi rakyat dari pemerintah dan NGO sudah ada sejak 3 tiga tahun sebelumnya.

Pada 2015 sebelum program dilakukan, terdapat 30 rumah tangga miskin, di desa tersebut. Angka tersebut meningkat menjadi 50 rumah tangga pada bulan April tahun 2016 ${ }^{1}$. Fenomena ini sangat kontradiktif dengan program pembangunan desa; dan menunjukkan bahwa pembangunan desa tidak berdampak secara langsung terhadap peningkatan kesejahteraan masyarakat. Pada desa-desa pesisir dan aliran sungai umumnya tersedia institusi ekonomi yaitu tauke sebagai

\footnotetext{
${ }^{1}$ Meskipun data tersebut belum diverifikasi, tetapi melalui wawancara ke berbagai pihak semua menyatakan informasi bahwa 50 rumah tangga miskin di Desa Sungai Tohor.
}

penjamin kelangsungan konsumsi. Ketersediaan kelembagaan penjamin ekonomi di pedesaan menyebabkan hukum produksi sama dengan konsumsi berlaku terbalik yaitu konsumsi sama dengan produksi bahkan peningkatan konsumsi tidak secara otomatis meningkatkan produksi. Konsumsi bisa meningkat, tetapi produksi tetap atau tidak meningkat bahkan bisa berkurang karena faktor alam seperti kemarau panjang, musim penghujan dan banjir dan krisis -krisis yang lainnya (Amady, 2014). Berdasarkan konstruksi teoritis tersebut maka tulisan ini menjawab pertanyaan berikut; Institusi apakah yang menjadi jaminan konsumsi rumah tangga petani sagu di Desa Sungai Tohor?

Hasil penelitian ini berkontribusi penting pada kajian antropologi ekonomi dan pembangunan pedesaan karena hasil studi ini mampu menjelaskan hubungan aspek sosial ekonomi dalam hal pencapaian pembangunan pedesaaan.

\section{Kajian Pustaka}

\section{Teori Konsumsi Pedesaan Subsisten}

Teori ekonomi subsisten dari Chayanov dan Elis $^{2}$ yang mengedepankan prinsip labor consume balance yaitu jumlah konsumsi sama dengan produksi; semakin kecil produksi semakin kecil konsumsi. Teori ini ternyata tidak berlaku di desa - desa di Riau; sebab di desa ini terdapat institusi penjamin keberlanjutan konsumsi yaitu para

\footnotetext{
${ }^{2}$ Chayanov (1966) dalam Ellis (1988) menyebut ekonomi subsisten ( sebagai labor consume balance ;s edangkan Evers (1991) menyebutnya sebagai penggunaan produksi langsung. Cahayanov menggambarkan ekonomi subsisten melalui houseshold utility maximisation (penggunaan utilitas rumah tangga secara maksimal sebagai usaha memaksimal potensi ekonomi rumah tangga melalui tenaga kerja rumah tangga tanpa bayar, dan memaksimalkan fungsi lahan pertanian yang sempit. Setiap produksi dicoba untuk mencapai keseimbangan antara produksi dan konsumsi. Semakin tinggi produksi semakin besar konsumsi. Semakin kecil produksi semakin kurang konsumsi.
} 
tauke (bos besar). Prinsip konsumsi berlebih, di mana hasil produksi berlebih dikonsumsi secara langsung tetap dijumpai di Riau (Amady, 2014). Temuan Dove (1985) di Kalimantan, Brewer (1985) di Bima, Schefold (1985) bahwa jumlah produksi bukan hanya menentukan konsumsi tetapi juga menentukan jam kerja pun juga tidak berlaku untuk kasus di pedesaan di Riau. $^{3}$

Konsumsi pedesaan Riau terbagi menjadi beberapa pola, pertama, jaminan konsumsi tahunan yang diimplementasikan melalui produksi tahunan berupa berladang berpindah-pindah dan bersawah dengan tanaman utamanya adalah padi. Kegiatan ini dikerjakan setahun sekali dan berfungsi memenuhi jaminan kebutuhan konsumsi tahunan. Jika panen padi gagal, warga mengandalkan tauke untuk kebutuhan konsumsi mereka (Amady, 2014).

Kedua, jaminan konsumsi harian. Sumber utama jaminan harian adalah tauke. ${ }^{4}$ Konsumsi rumah tangga pedesaan di Riau sepenuhnya dijamin oleh tauke melalui sistem hutang. Hasil produksi mingguan atau bulanan berupa hasil getah karet, sawit atau hasil alam lainnya, termasuk ikan diserahkan langsung ke tauke sebagai jaminan konsumsi berikutnya. Sistem pertukaran rumah tangga dengan tauke melalui aktivitas produksi menderes pohon karet, membalak kayu, mengambil rotan, damar dan semua kekayaan hutan sebagai aktivitas bulanan yang hasilnya diserahkan ke tauke. Tauke. Warga juga menanam

\footnotetext{
3 Jika kerja dalam 60 jam cukup untuk konsumsi sebulan maka dalam sebulan mereka hanya bekerja selama maksimal 60 jam, Sebaliknya, jika produksi selama sebulan tidak mencukupi konsumsi minimum rumah tangga, maka total konsumsi akan diminimalisir, jam kerjapun semakin banyak

4 Tauke, secara historis sudah sejak abad ke 18 bahkan mungkin sebelumnya tauke sudah hadir di komunitas maritim (nelayan). Jadi sudah sangat mendarah daging pada masyarakat pesisir dan aliran sungai (maritim). Sedemikian lamanya bertahan sistem ini, menandakan bahwa nilai-nilai tauke sudah turunkan secara turun menurun dan sudah menjadi nilai dan norma yang dipatuhi (Amady, 2014).
}

sayuran, menangkap ikan dan memetik sayuran liar untuk melengkapi jaminan dari tauke,.

Ketiga, jaminan konsumsi sosial dan keluarga. Rumah tangga desa di Indonesia menyediakan secara khusus hasil produksi untuk konsumsi sosial, terutama berbagi dengan sanak saudara yang sudah berbeda rumah, gotong royong untuk biaya pesta pernikahan, kematian, kelahiran, pendidikan dan hari lebaran. Konsumsi ini merupakan rangkaian produksi karena rumah tangga yang terlibat pada konsumsi sosial tersebut dikembalikan lagi dalam bentuk yang sama ketika rumah tangga tersebut memerlukan sumber konsumsi massal.

Konsumsi sosial cenderung berupa pengalihan tenaga kerja dari tenaga kerja rumah tangga menjadi tenaga kerja desa yang juga tidak dibayar. Pengalihan tenaga kerja ini diimplementasikan melalui sistem tolong menolong atau gotong royong (Sayogyo dan Pudjiwati, 1996). Tolongmenolong dilakukan antar petani yang bertetangga atau satu kelompok usaha atau kerabat dekat.

Adapun beberapa konsumsi massal antara lain sebagai berikut; $a$ ). suatu massa tertentu terjadi penurunan harga komoditas, gelombang besar atau terjadi persitiwa alam atau kepala rumah tangga sakit keras; $b$ ). hari-hari besar agama seperti hari raya Idul Fitri, Idul Adha, muharam atau hari-hari besar adat. Pada hari itu semua masyarakat memaksimalkan konsumsi untuk merayakan hari besar tersebut sampai tiga hari. Selain biaya untuk makan juga pembelanjaan tahunan berupa pakaian dan penghiasan rumah; c). perayaan perkawinan, kelahiran anak, tujuh bulanan, kematian dan lainnya. Sumber konsumsi tersebut biasanya berasal dari harta kekayaan berupa tanah, kebun dan binatang ternak yang dijual dan berhutang pada tauke (tauke) dan juga pemberian dari anggota komunitasnya; $d$ ). ada sebagian kecil dari keluarga yang ingin memperbaiki hari tuanya melalui pendidikan. Anak yang sekolah memerlukan dana besar apalagi 
kalau sampai kuliah di perguruan tinggi. Sumber biayanya kekayaan berupa tanah, kebun, ternak dan perhiasan dan meminjam uang ke tauke;

\section{Tauke Sebagai Jaminan Keberlanjutan Konsumsi}

Tauke $^{5}$ yang dimaksud pada tulisan ini adalah tauke sebagai pedagang, kreditor dan pengumpul yang secara aktif menyediakan fasilitas hutang kepada rumah tangga petani dan nelayan. Posisi tauke menguasai sumber daya ekonomi dan membangun jaringan pasar yang lebih luas. Tauke merupakan institusi sosial-ekonomi di desa yang mengatur proses produksi, distribusi dan konsumsi, di mana aktivitas ekonomi di desa berpusat pada tauke. Tauke adalah institusi ekonomi desa sebagai penjamin kelangsungan konsumsi rumah tangga petani pada musim penghujan atau gelombang laut besar yang menjalankan perniagaan; sebagai pedagang, tauke menjual kebutuhan harian kepada masyarakat desa secara hutang; sebagai pengumpul, tauke membeli hasil pertanian untuk dijual ke pasar; dan sebagai kreditor tauke meminjamkan uang kepada warga desa. (Amady, 2014)

Mekanisme jaminan tauke ke warga di desa melalui hutang. Tauke menyediakan fasilitas hutang bagi setiap warga desa, baik melalui barang maupun uang tunai. Ketika seseorang, telah mendapat fasilitas hutang maka secara otomatis mendapat fasilitas jaminan konsumsi selama masih mempunyai hutang. Hutang menjadi tanda pengikat kewajiban tauke memenuhi kepastian jaminan konsumsi rumah tangga di desa.

\footnotetext{
5 Tauke juga tidak identitk dengan etnis Tionghoa. Tauke merupakan institusi ekonomi pedesaan terutama di pesisir yang bisa diperankan oleh siapa saja dan etnis mana saja, yang tidak selalu menamai dirinya tauke tetapi sangat tergantung pada idiom lokal. Tauke tidak sama dengan rentenir dan tengkulak, tauke dalam proses hutang tidak mengenal jaminan, bunga dan periode jatuh tempo. Rentenir dan tengkulak meminjamkan uang memerlukan jaminan, bunga dan jatuh tempo hutang, seperti musim panen.
}

Berhutang ke tauke sangat mudah dan simple tanpa syarat, tanpa jaminan, tanpa pecatatan, tidak ada waktu jatuh tempo dan tidak harus dilunaskan, yaitu harus dipercaya oleh tauke. Untuk mendapat kepercayaan dari tauke diperlukan kepemilikan perangkat produksi berupa kebun atau kapal tangkap, atau menjadi pekerja di kebun atau kapal tangkap milik tauke.

Tauke tidak menginginkan piutangnya diunasi. Hutang bagi tauke merupakan mekanisme transaksi yang mengikat, di mana hasil produksi petani diharuskan dijual ke tauke sebagai alat pembayar hutang dengan harga ditentukan secara sepihak oleh tauke. Bagi tauke semakin banyak rumah tangga berhutang semakin besar aset dan semakin besar keuntungan. Seorang tauke dinyatakan berhasil jika semakin banyak jumlah piutang kepada rumah tangga di satu desa. Jika tauke sudah tidak bisa lagi memberi hutang kepada rumah tangga di desa, maka secara otomatis tauke akan bankrut dan piutangpun tidak dapat ditagih.

\section{Metode}

Penelitian ini dilaksanakan selama dua bulan yaitu bulan April dan Mei 2016. Penelitian ini dilakukan dengan menggunakan metoda kualiatif. Teknik pengumpulan data dilakukan dengan studi kepustakaan, observasi, dan wawancara. Studi pustaka dilakukan dengan menelusuri informasi dan buku-buku terkait di perpustakaan dan internet untuk mendapatkan konsep dan terori serta data sekunder. Observasi dilakukan dengan cara tinggal bersama warga untuk mengamati berbagai aktivitas petani sagu, pabrik sagu dan pemilik pabrik sagu. Wawancara mendalam dilakukan pada 13 informan yang dipilih secara purposive yang dianggap kompeten dengan memperhatikan keragamannya. Para infoman dalam penelitian ini antara lain tokoh masyarakat, aparat desa, dan masysrakat umum yang dipilih secara teknik 'snow ball'. Analisis deskriptif dilakukan pada data lapangan. Validitas data dilakukan 
dengan cara crosschecking, summarising, synthesizing.

\section{Hasil dan Pembahasan}

\section{Daerah Penelitian $^{6}$}

Desa Sungai Tohor merupakan satu di antara 10 desa $^{7}$ di Kecamatan Tinggi Timur, Kabupaten Meranti Provinsi Riau. Desa ini juga merupakan ibu kota kecamatan.

\section{Peta 1 : Peta Wilayah Desa Sungai Tohor}

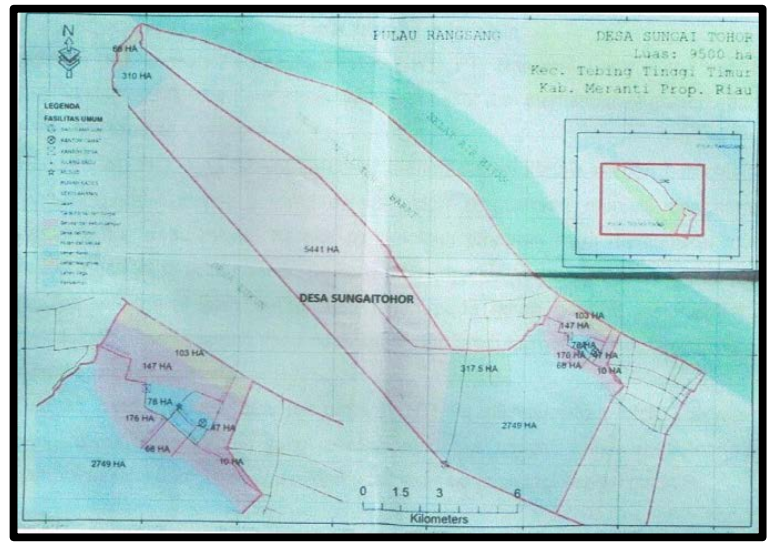

Sumber : Profil Desa Sungai Tohor

Tahun 2012 Desa Sungai Tohor dimekarkan menjadi desa Sungai Tohor dan Desa Sungai Tohor Barat dengan pembatas wilayahnya adalah Sungai Tohor. Tahun 2015 jumlah penduduk Desa Sungai Tohor 1.273 jiwa terdiri atas 337 kepala keluarga, 665 lelaki dan 608 perempuan, dengan rata- rata anggota setiap KK berjumlah 4 orang. Secara etnis, komposisi penduduk terdiri dari 1.249 jiwa suku Melayu, 9 Suku Jawa, 5 Suku Batak, 3 suku minang dan 7 suku lainnya. Semuanya penduduknya bergama Islam. Di desa ini masih terdapat 5 warga yang buta huruf dan 34 orang putus sekolah. Latar belakang pendidikan, 490

\footnotetext{
${ }^{6}$ Sebagian besar sumber datanya dikutip dari profil Desa Sungai Tohor tahun 2015

${ }^{7}$ Adapun wilayahnya terletak di Pulau Tebing Tinggi bagian timur yaitu Sungai Tohor, Sungai Tohor Barat, Teluk Buntal, Kapau Baru, Batin Suir, Lukum, Tanjung Sari, Nipah Sendanu, Sendanu Darul Ihsan, dan Tanjung Gadai. Desa Sungai Tohor merupakan ibu kota Kecamatan Tebing Tinggi Timur, Kabupaten Kepulauan Meranti
}

orang tamat sekolah dasar, 181 sekolah menengah (SMP), 206 tamat SMA, 7 tamat diploma, 56 orang tamat S-1, dan 2 orang taman S - 2. Kompososi pendidikan juga tergambar di pekerjaan, 18 orang pegawai negara (ASN), 117 buruh /karyawan, 46 tenaga honorer, 21 pedagang, dan 340 petani.

Penghubung satu-satunya antara Desa Sungi Tohor denan ibu kota Kabupaten adalah melalui laut, meskipun secara terbatas juga dapat menggunakan jalur darat dengan sepeda motor. Desa ini merupakan penghasil utama sagu terbesar di kecamatan Tebing Tinggi Timur. Dari 9500 ha lahan di wilayah ini, terdapat 200 hektar lahan padi ladang, 1.20 hektar kebun karet dan 2650 hektar kebun sagu, 2 hektar kebun kelapa dan 3 hektar pinang. Di desa ini terdapat 13 kilang sagu, dengan produksi 7.200 ton per tahun atau senilai Rp. 1.290.000.000,-. Selain menghasilkan tepung sagu basah, kilang juga menghasilkan sagu olahan berupa kerupuk sagu, sagu mutiara sagu dan mie. Ekonomi di Desa Sungai Tohor juga ditopang oleh sumber lain yaitu produksi padi, batu bata, dan perabot. .

\section{Sagu di Sungai Tohor}

Masyarakat memulai budidaya sagu pada 1985, Budidaya sagu menunjukan hasil yang menggiurkan. Hal itu terbukti dari peralihan budidaya dari padi ke sagu pada 1990. Pada tahun itu seluruh rumah tangga telah beralih dari menanam padi ke sagu. Pada 1995, sekretaris desa mendapat bantuan mesin pengolahan kilang sagu melalui dana BANPRES (Bantuan Presiden). Sejak itu kilang sagu berkembang di Desa Sungai Tohor hingga terdapat 14 Kilang Sagu; ( walau kini yang aktif hanya 13). Tepung sagu dijual ke tauke di luar desa untuk di pasarkan di Malaysia. Di desa ini terdapat 13 tauke sagu yaitu Amrizal, Dedi, Izam, Zamhur, Endi, Cek Manan, Abdul Jalil, Moher, Wak Nong, Arif, P2K, Azmi dan Mustofa.

Pada 1995 setiap rumah tangga memiliki kebun sagu minimal 1,5 hektar. Saat itu ada 
pembagian bibit sagu dari pemerintah untuk seluruh rumah tangga. Warga masih bisa membuka lahan dengan leluasa karena belum hadir perusahaan swasta nasional di kawasan perladangan mereka.

Pada 2015 terdapat 30 rumah tangga yang tidak memiliki kebun sagu dan kebun karet. Jumlah rumah tangga tanpa lahan garapan ini kemudian meningkat menjadi 50 pada 2016. Pohon sagu bagi masyarakat Sungai Tohor merupakan tanaman tabungan (saving) untuk konsumsi massal seperti untuk perayaan pesta pekawinan atau pernikahan, kelahiran, untuk biaya berobat, untuk sekalah anak, dan biaya syukuran lainnya. Pemenuhan kebutuhan harian, dan mingguan rumah tanga dari sekitar 150 orang warga didapat dari hasil bekerja di kilang-kilang sagu yang beroperasi dua kali sebulan. Selain itu hasil dari bekerja sebagai buruh, menderes getah karet, mengumpul pinang dan buruh harian lainnya juga menjadi sumber pendapatan. Jumlah petani di desa ini mencapai 340 jiwa yang meliputi petani karet, sagu dan pinang.

Pemilik kebun sagu mempunyai beberapa pilihan dalam pengelolaan sagu milik mereka. Pilihan pertama, menjual langsung batang sagu ke kilang sagu. Hargadihitung berdasarkan kadar ketinggian sagu. . Satu tual sagu dihargai Rp.50.000,-; dan sebatang pohon sagu bisa menghasilkan 10 sampai 12 tual. Dengan demikianm satu batang pohon sagu dihargai sekitar 500.00 hingga 600.000 rupiah. Setiap rumah tangga dapat menjual 40 sampai 120 batang sagu setiap kali jual. Harga sagu di Desa Sungai Tohor berbeda dengan harga sagu di Desa Sungai Tohor Barat. Harga per tual saja selisih 10 hingga 15 ribu rupiah. Hal ini karena penjual tua sagu di Desa Tohor Barat membawa tual sagunya ke muara sungai untuk dibeli oleh tuake dari Selat Panjang.

Pilihan kedua, warga dapat mengolah sendiri batang sagunya di kilang. Jika belum mempunyai kilang sendiri warga bisa sewa dari kilang yang sudah sudah ada dengan harga sewa Rp.120.000 per ton sebelum tahun 2016, dan sejak tahun 2016 harga sewa per ton Rp.230.000,- Semua proses kilang mulai dari tebang, pemotongan, pengupasan kulit dan penggilingan dilakukan sendiri oleh penyewa dengan tenaga sekitar 15 orang. Setiap orang diberi upah Rp.110.000 perhari. Setiap kali proses kilang setidaknya ada 105 tual sagu atau 36.750 kilo atau 36 ton yang dihasilkan. Para pemilik kilang sagu dan yang mengelola sendiri sagunya mendapat keuntungan 650 per ton setiap kali giling. Proses pengerjaannya mulai dari tebang hingga ke pengolahan tepung sagu basah di kilang memakan waktu satu bulan. Setiap langkah proses pengerjaan dilakukan oleh pekerja yang berbeda-beda. Kilang mengelola sagu menjadi sagu tepung basah yang kemudiandijual ke Asiong, salah satu tauke besar dari 13 kilang Sagu di Sungai Tohor ke Selat panjang. Petani sagu yang mempunyai persedian uang terbatas tidak memungkinkan untuk mengambil pilihan kedua ini, karena memakan waktu sebulan dan harus mengeluarkan biaya terlebih dahulu untuk menggaji buruh.

Pilihan ketiga, menjual dengan sistem pajak, yaitu petani mengijonkan sagunya kepada “ tauke”8. Pilihan ini biasanya dilakukan untuk memenuhi konsumsi massal berupa biaya sekolah anak, berobat, pernikahan, kematian, lebaran dan dana - dana massal yang mendesak lainnya. Di Desa Sungai Tohor, tauke (pemilik kilang sagu) berperan layaknya sistem ijon (tengkulak). Pola hubungan antara pemilik kilang sagu dengan pemilik kebun hanya dalam bentuk hubungan ekonomi, hutang berdasarkan jaminan ketersedian pohon sagu. Jaminan sosial dan konsumsi harian tidak disediakan oleh tauke pemilik kilang sagu. Petani sagu

\footnotetext{
${ }^{8}$ Konsep tauke di Desa Sungai Tohor adalah layaknya pengijon atau tengkulak, petani menjual sagu ketika sagu belum layak panen dengan harga yang murah karena sangat membutuhkan uang. Ijon dalam Kamus Besar Bahasa Indonesia adalah (1) pembelian padi dsb sebelum masak dan diambil oleh pembeli sesudah masak (2) kredit yg diberikan kpd petani, nelayan, atau pengusaha kecil, yg pembayarannya dilakukan dengan hasil panen atau produksi berdasarkan harga jual yg rendah;
} 
yang membutuhkan uang cepat sementara sagu baru bisa berproduksi satu tahun atau dua tahun bahkan empat tahun kemudian maka pilihan yang diambil petani sagu adalah memilih melalui pajak yaitu menjual batang sagu dengan harga jual saat itu per batang. Semakin lama sagu bisa ditebang semakin murah harga batang sagu tersebut. Akumulasi kebutuhan massal warga menyebabkan berpindahnya kebun sagu warga kepada pemilik kilang sagu (tauke sagu).

Proses pajak dapat gambarkan sebagai berikut; , ketika tahun ajaran tiba (bisa juga karena keluarga yang sakit, pesta perkawinan atau pergi haji ke mekah) seorang ayah dari anak yang akan bersekolah mendatangi tauke untuk menjual sagunya yang belum layak di panen. Lalu tauke bersama pemilik sagu melihat sagu yang akan dijual dengan maksud menentukan harga jual; biasanya bergantung pada lamanya sagu itu bisa di panen. Jika setelah disurvey ternyata sagunya baru bisa dipanen setahun kemudian, maka harga perbatangnya biasantya 50 ribu lebih rendah dari yang berlaku di pasaran. Misal jika harga di pasaran Rp. 300.000,- perbatang maka harga sagu yang baru bisa dipanen setahun kemudian dihargai Rp.250.000,- per batang. Pengurangan 50 ribu rupiah berlaku setiap kelipatan tambahan tahun bisa dipanen. Jika sagu yang dijual baru bisa dipanen dua tahun kemudian maka harga satu batang sagu turun menjadi Rp.200.000,- karena sudah dikurangi seratus Rp.100.000,- untuk kompensasi selama dua tahun. Implikasi lain adalah pohon sagu yang belum dijual hanya bisa dijual ke tauke tempat sagu dipajak.

Sistem pengurangan harga pertahun 50 ribu rupiah juga berlaku bagi petani yang sudah menjual sagu dengan sistem pajak tetapi sagunya belum tiba masa panen jika petani memajak kembali sagunya. Misalnya, seorang petani sudah memajak 120 batangnya sagunya, masih tersisa 80 batang sagu lagi. Jika waktu untuk panen sagu sudah dipajak adalah dua tahun. Setahun kemudian petani sangat membutuhkan uang untuk sekolah anaknya lalu datang lagi kepada tauke untuk menjual pohon sagu tersisa. Maka 80 batang sagu tersebut dihargai 200 ribu perbatang, dengan pertimbangan sagu yang dijualnya itu baru bisa dipanen setahun kemudian maka harga perbatangnya dikurangi Rp.50.000,- tetapi karena sagu yang dipajak sebelumnya masih belum panen maka petani harus rela menerima harga sagunya dikurangi Rp.50.000,- perbatang. Jika harga Rp.300.00,- per batang, karena dijual dengan sitem pajak selama setahun harga menjadi Rp.250.000,- namun karena petani masih terikat dengan pajak sebelumnya harga perbatang sagu dihargai menjadi Rp.200.000,-

Jika petani masih sangat membutuhkan uang sementara pohon sagu tidak tersedia lagi untuk dipajak, maka pada kebiasaanya yang telah terjadi petani tersebut menjual tanah yang ditanami sagu 200 batang yang sudah sudah dipajak tersebut kepada tauke tempat dia memajak dengan harga yang ditetapkan oleh tauke. Akumulasi kebutuhan massal warga menyebabkan berpindahnya kebun sagu warga kepada pemilik kilang sagu (tauke sagu). Umumnya dari 50 rumah tangga yang dinyatakan miskin pada 2015 telah mengalami proses ini. Dengan kata lain, sistem pajak sagu menjadi faktor pemercepat kemiskinan.

\section{Jaminan Institusi Keluarga}

Secara umum hanya terdapat dua institusi penjamin kelangsungan konsumsi rumah tangga, pertama, institusi keluarga. Keluarga pada definisi ini merujuk ke keluarga luas, yaitu rumah tangga yang berasal dari keturunan yang sama. Rumah tangga di desa Sungai Tohor memang berasal satu keturunan yang datang dari wilayah Pangkalan Kerinci. Oleh sebab itu solidaritas keluarga menjadi penting dan ditaati sebab menjadi jaminan kepastian tersedianya konsumsi harian. Solidaritas keluarga tersebut menyebabkan rumah tangga di desa Sungai Tohor tidak menjual sagu ke desa lain walaupun harganya lebih tinggi. 
Mekanisme jaminan bersifat konvensional, di mana pihak rumah tangga yang masih terikat dengan keluarga luas dan masih dekat hubungan ikatan keluarganya membantu secara sukarena kebutuhan konsumsi hariannya secara terbatas. Pinjaman dapat berupa pinjaman uang atau bahan tanpa bunga dan tanpa jaminan. Pembayaran pinjaman tanpa batas waktu dengan nilai yang sama dengan yang dipinjam dan dibayar jika peminjam telah berkemampuan untuk mengembalikannya.

Sumber pinjaman lain adalah tauke sagu tempat bekerja, setiap pekerja di kilang sagu bisa meminjam uang dengan jaminan gaji, atau gaji dibayar di muka. Pinjaman ini hanya diperbolehkan sebesar gaji yang diterima. Pinjaman ke tauke sagu ini dipergunakan untuk memenuhi kebutuhan harian. Tauke pemilik kilang sagu hanya meminjamkan uang saja ke buruh hariannya tanpa jaminan lain. Umumnya buruh yang bekerja dikilang sagu masih memiliki hubungan keluarga dengan pemilik kilang sagu atau petani yang menyewa kilang sagu.

\section{Jaminan Kebun Sagu}

Kebun sagu memegang peranan penting dalam hal penjaminan konsumsi massal. Apalagi sagu dari tahun ke tahun akan mengalami peningkatan produksi dengan sekali tanam saja pada tahun kedua peningkatan produksinya mencapai 200\%. Jika menaman satu jalur sebanyak 120 batang sagu, maka pada panen pertama kali berkisar 120 batang pada saat panen kedua mencapai 300 batang karena perkembangan tunas sagu yang cepat dan banyak.

Kebun sagu juga memberi ruang kepada rumah tangga untuk terlibat dalam sistem pajak untuk pemenuhan konsumsi massal. ${ }^{9}$

\footnotetext{
${ }^{9}$ Pajak merupakan institusi hutang dengan cara menjual pohon sagu yang belum layak panen. Pemberi pinjaman dengan pajak adalah pemilik pabrik sagu di desa dengan sistem layaknya sistem ijon. Masyarakat menyebut pemberi pajak dengan istilah tauke dan fungsi dan perannya berbeda dengan tauke
}

Sagu di Sungai Tohor berkontribusi terhadap konsumsi rumah tangga melalui hasil produksi dan melalu serapan tenaga kerja. Industri sagu di Desa Sungai Tohor membutuhkan sumber daya buruh yang cukup besar. Satu pabrik sagu membutuhkan sedikitnya 9 - 15 tenaga kerja sebagai pekerja buruh harian, untuk menebang, memotong tual, mengupas kulit dan mengolah pohon sagu menjadi tepung sagu basah. Jumlah buruh yang diserap oleh kilang sagu mencapai 117 orang. Perhitungan jumlah buruh ini tidak termasuk buruh rumah tangga tanpa di bayar dari pemilik kebun.

Bekerja sebagai buruh harian lepas kilang sagu juga menjadi andalan untuk memenuhi kebutuhan harian. Gaji buruh berkisar Rp.110.000,- per hari dengan masa kerja paling lama 15 hari sebulan. Dengan demikian nilai penghasilan yang diperoleh setiap bulan diperkirakan Rp.1.500.000,Jumlah ini cukup memadai untuk memenuhi kebutuhan konsumsi harian rumah tangga. Pada umumnya, buruh harian meminjam uang terlebih dahulu sebelum memulai kerja karena tidak tersedia uang untuk memenuhi kebutuhan konsumsi hariannya.

\section{Biaya Pendidikan dan Berobat}

Pemerintah pusat dan pemerintah daerah perlu memberi solusi cepat kepada rumah tangga di desa Sungai Tohor. Terdapat dua konsumsi massal yang sebenarnya sudah menjadi tangung jawab pemerintah, yaitu kesehatan dan pendidikan.

Pertama, animo anak-anak yang bersekolah sudah sangat kuat sehingga jumlah lahan sagu terbatas tidak bisa menjamin ketersediaan biaya sekolah anaknya, apalagi anak lebih dari satu. Maka kebijakan yang

\footnotetext{
layaknya sistem ijon, sagu dijual sebelum masa panen untuk mmenuhi konsumsi massal. Fungsi jaminan konsumsi tidak dijumpai pada pengetian ini, baik harian maupun konsumsi massal, pertukaran hanya terbatas nilai uang yang diterima saja tidak ada jaminan sosial lainnya.
} 
diperlukan adalah jaminan pendidikan dari negara, untuk pembiyaan sekolah anakanaknya sejak sekolah dasar hingga perguruan tinggi

Kedua, biaya berobat. Biaya berobat merupakan sumber kedua penyebab beralihnya kepemilikan kebun sagu petani ke tauke, umumnya warga desa belum memahami makna BPJS (Badan Penyelengaara Jaminan Sosial) kesehatan bahkan mereka juga belum tahu apa itu BPJS kesehatan. Selain itu, tempat untuk berobat cukup jauh dari desa, harus ke Selat Panjang, ibu kota kabupaten atau bahkan ke Pekanbaru ibu kota provinsi. Perjalanan tersebut memerlukan biaya sementara tidak tersedia cadangan biaya untuk berobat. Seringkali, warga mesti menjual tanah jika pohon sagu sudah tidak tersedia lagi untuk di pajak. Oleh karena itu penyediakan fasilitas pengobatan yang memadai di desa atau di kota kecamatan yang bisa dijangkau dengan cepat dan mudah dan dibiaya oleh negara merupakan hal penting bagi warga. Jika dua konsumsi massal ini bisa ditanggung oleh pemerintah maka beban konsumsi bagi rumah tangga di Desa Tohor akan menjadi lebih ringan.

\section{Simpulan}

Penelitian ini berkesimpulan; pertama, penelitian ini melaporkan bahwa tidak semua desa pesisir yang berada bibir laut merupakan desa nelayan. Desa-desa di Kabuputen Kepulauan Meranti justru berorientasi ke darat terutama tanaman keras. Sementara potensi laut yang sangat besar belum menjadi sumber daya ekonomi. Pemerintah perlu mempertimbangan temuan ini agar tidak seragam dalam menerapkan kebijakan pembangunan bagi desa-desa pesisir dan melakukan reorientasi sumber daya ekonomi laut yang tersedia, selain daratan.

Kedua, melihat pentingnya posisi tauke sebagai penjamin keberlanjutan konsumsi rumah tangga, maka pemerintah perlu membuat institusi tandingan yang menjalankan fungsi tauke. Institusi di mana yang bertindak sebagai penjual kebutuhan pokok, pembeli produk pertanian masyarakat dan menyediakan jasa peminjaman uang tanpa jaminan dan mudah.

Ketiga, perlu upaya melalui kebijakan dan sosialisasi kembali agar sagu menjadi makanan pokok sebagaimana beras. Upayaupaya mengembalikan sagu sebagai makanan utama memerlukan langkahlangkah yang stategis dan berkelanjutan. Beras bukan satu-satunya makanan pokok melainkan meletakan sagu sebagai makanan utama selain beras. Jika masyarakat kembali ke sagu sebagai makanan pokok, maka beban pengeluaran bagi rumah tangga di desa Sungai Tohor semakin ringan.

\section{Daftar Pustaka}

Amady, M.Rawa El, 2014, Tauke dan Budaya Hutang; Perubahan Sosial-Budaya pada Masyarakat Desa, Yogyakarta, AG Litera dan Padi Institute.

Brewer, Jeffrey D, 1985, Penggunaan Tanah Tradisional dan Kebijakan Pemerintah Bima 1925 - 1975, dalam Michael R. Dove (editor) Peranan Kebudayaan tradisional Indonesia dalam Moderniasi. PT Midas Surya Grafindo, Yogyakarta.

Chayanov, A.V. 1966, The Theory Of Peasant Economy, Illonis : Homewood.

Dove, Michael R. 1985, Mitos Rumah Panjang "Komunal" dalam pembangan pedesaan: Kasus Suku Kantu Kalimantan Tengah, dalam Michael R. Dove (editor) Peranan Kebudayaan Tradisional Indonesia dalam Moderniasi. PT Midas Surya Grafindo, Yogyakarta.

Ellis, Frank, 1988, Peasant Economics, Farm Households and Agrarian Development, Cambridge : Cambridge University Press.

Ever. Hans-Dieter, 1991, “Teori Produksi Subsistensi dan Produksi Tak Formal” dalam Jurnal Antropologi Sosiologi No.19, Bangi : UKM. 